\title{
Geophysical and geochemical signatures of Gulf of Mexico seafloor brines
}

\author{
S. B. Joye ${ }^{1}$, I. R. MacDonald ${ }^{2}$, J. P. Montoya ${ }^{3}$, and M. Peccini ${ }^{2}$ \\ ${ }^{1}$ Department of Marine Sciences, University of Georgia, Athens, Georgia 30602, USA \\ ${ }^{2}$ School of Physical and Life Sciences, Texas A\&M University, Corpus Christi, Texas, USA \\ ${ }^{3}$ School of Biology, Georgia Institute of Technology, Atlanta, Georgia 30332, USA
}

Received: 21 April 2005 - Published in Biogeosciences Discussions: 31 May 2005

Revised: 30 August 2005 - Accepted: 23 September 2005 - Published: 28 October 2005

\begin{abstract}
Geophysical, temperature, and discrete depthstratified geochemical data illustrate differences between an actively venting mud volcano and a relatively quiescent brine pool in the Gulf of Mexico along the continental slope. Geophysical data, including laser-line scan mosaics and subbottom profiles, document the dynamic nature of both environments. Temperature profiles, obtained by lowering a CTD into the brine fluid, show that the venting brine was at least $10^{\circ} \mathrm{C}$ warmer than the bottom water. At the brine pool, thermal stratification was observed and only small differences in stratification were documented between three sampling times (1991, 1997 and 1998). In contrast, at the mud volcano, substantial temperature variability was observed, with the core brine temperature being slightly higher than bottom water (by $2^{\circ} \mathrm{C}$ ) in 1997 but substantially higher than bottom water (by $19^{\circ} \mathrm{C}$ ) in 1998 . Detailed geochemical samples were obtained in 2002 using a device called the "brine trapper" and concentrations of dissolved gases, major ions and nutrients were determined. Both brines contained about four times as much salt as seawater and steep concentration gradients of dissolved ions and nutrients versus brine depth were apparent. Differences in the concentrations of calcium, magnesium and potassium between the two brine fluids suggest that the fluids are derived from different sources, have different dilution/mixing histories, or that brine-sediment reactions are more important at the mud volcano. Substantial concentrations of methane, ammonium, and silicate were observed in both brines, suggesting that fluids expelled from deep ocean brines are important sources of these constituents to the surrounding environment.
\end{abstract}

$\overline{\text { Correspondence to: } \mathrm{S} \text {. B. Joye }}$

(mjoye@uga.edu)

\section{Introduction}

Submarine mud volcanoes are conspicuous examples of focused flow regimes in sedimentary settings (Carson and Screaton, 1998) and have been associated with high thermal gradients (Henry et al., 1996), shallow gas hydrates (Ginsburg et al., 1999), and an abundance of high-molecular weight hydrocarbons (Roberts and Carney, 1997). Mud volcanoes are common seafloor features along continental shelves, continental slopes, and in the deeper portions of inland seas (e.g., the Caspian Sea, Milkov, 2000) along both active and passive margins. Factors contributing to the formation of mud volcanoes include high sedimentation rates, tectonic activity, and tectonic compression (reviewed by Milkov, 2000). Along passive margins, mud volcanoes are associated with areas of rapid sedimentation (e.g., submarine fans such as the Niger Delta) or areas of high sedimentation combined with salt or shale tectonic activity (e.g., the Gulf of Mexico) (Milkov, 2000). Along active margins, mud volcanoes are associated with accretionary prisms (e.g., the Mediterranean Sea, Limonov et al., 1996; offshore Barbados, Lance et al., 1998; Langseth et al., 1988).

When salt diapirs breach the sediment-water interface or extend to the shallow sub-bottom depths $(<50 \mathrm{~m}$; Reilly et al., 1996), brine-dominated seepage drives formation of brine-filled basins or smaller brine pools (Roberts and Carney, 1997). Brine-filled basins with diameters of several kilometers and depths of hundreds of meters are known from the Mediterranean Sea (Cita, 1990; Cita et al., 1989; De Lange and Brumsack, 1998; MEDINAUT/MEDINETH, 2000) and the outer continental slope of the Gulf of Mexico (Sheu, 1990; Bouma and Bryant, 1994; MacDonald et al., 1990; Neurauter and Bryant, 1990; Neurauter and Roberts, 1994; Shokes et al., 1977). Geochemical profiles through the seawater-brine interface in these basins show

(C) 2005 Author(s). This work is licensed under a Creative Commons License. 


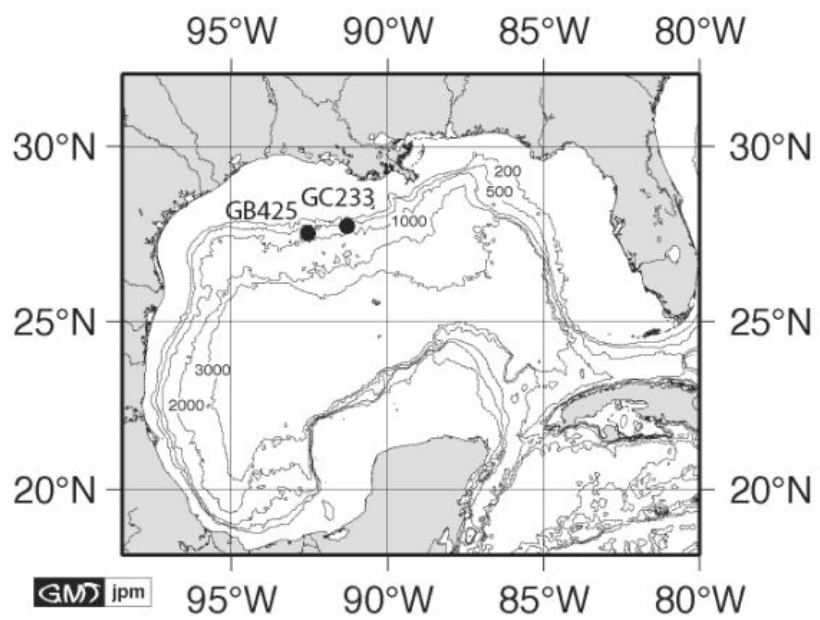

Fig. 1. Map showing the location of the study sites.

steep concentration gradients of dissolved oxygen and redox metabolites as well as temperature and salinity (Anschutz et al., 1998; Van Cappellen et al., 1998). Smaller brinefilled features form following rapid fluid expulsion, dissolution of shallow salt bodies, and/or the coalescence of salt diapirs which generate surface depressions that gradually fill with brine through lateral density flows (Bryant et al., 1990; Bryant et al., 1991; MacDonald et al., 1990; Roberts and Carney, 1997). These brine pools form a stable interface with seawater at the level of the crater rim (MacDonald et al., 1990). Sulfide-rich brines also occur as aquatanes at the base of deep-sea escarpments, for example on the western margin of the Florida platform (Commeau et al., 1987), where they are associated with abundant biomass of chemoautotrophic fauna.

Mud volcanoes, brine pools and brine basins are common in the Gulf of Mexico, an economically important hydrocarbon basin containing late Jurassic age oil and gas that was deposited in a diverse array of structural settings (Macgregor, 1993). The character of the Gulf of Mexico was shaped profoundly by the tectonics of a early Jurassic salt deposit (Pindell, 1985), which underlies the northwestern margin of the basin and has deformed and mobilized (Humphris, 1979) upward and to the south under the weight of Neogene sediments (Worrall and Snelson, 1989). Uplift or withdrawal of salt bodies creates diapirs or basins, respectively, that spawn irregular seafloor topography (Bryant et al., 1991) and fault networks that serve as conduits for the rapid transfer of brines, oil, and gas from deep reservoirs through the overlying sediments and ultimately into the water column (Kennicutt et al., 1988a and 1988b; Aharon et al., 1992a; Roberts and Carney, 1997). The association of dense chemoautotrophic-based communities with brine-dominated seeps has been documented in the Gulf of Mexico and elsewhere (e.g., Brooks et al., 1990; MacDonald et al., 1990; Milkov et al., 1996).
Brine-filled pools and basins contain a distinct volume of dense fluid retained below the level of the surrounding seafloor but in contact with the overlying seawater. Sampling the fluid from these often small, shallow basins and defining their morphology has been challenging. Here we present data describing the geochemistry and geophysics of a mud volcano and a stable brine pool in the northern Gulf of Mexico. We combine new results with previously published findings to describe distinct fluid flow regimes and geochemical processes at the two sites.

\section{Methods}

\subsection{Site characterization}

In May 1998, the submarine NR-1 (and her tender M/V CAROLYN CHOUEST) was used to survey two brinedominated cold seeps in the Gulf of Mexico: site GB425 $\left(27^{\circ} 33.2^{\prime} \mathrm{N}, 92^{\circ} 32.4^{\prime} \mathrm{W} ; 600 \mathrm{~m}\right.$ water depth) and site GC233 $\left(27^{\circ} 43.4^{\prime} \mathrm{N}, 91^{\circ} 16.8^{\prime} \mathrm{W} ; 650 \mathrm{~m}\right.$ water depth) (Fig. 1). The NR-1 was equipped with an EdgeTech X-star CHIRP system (2-12 kHz subbottom profiler) and a Raytheon LS4096 laser line scanner. The subbottom profiler was used to obtain highresolution imaging of near-bottom sediment layers while the laser line scanner was used to produce high-resolution, largearea surface images of the seafloor.

\subsection{Collection of brine samples}

Temperature profiles through the brines and/or collection of discrete vertical brine samples were obtained during research cruises on board the RV Seward Johnson II using the research submersible Johnson Sea Link II (Harbor Branch Oceanographic Institute) in 1991, 1997, 1998 and 2002. During these cruises, temperature profiles through these brine pools were obtained by lowering a SBE19 CTD into each pool using a small winch mounted on the submersible. The CTD was not available for the 2002 expedition, when we collected samples for detailed geochemical and microbiological analyses.

An instrument called the "brine-trapper" (Fig. 2) was used to collect discrete depth samples of brine during cruises in 1998 and 2002. For the 1998 brine-trapper samples, only a limited number of geochemical analyses were performed. However, for the 2002 brine-trapper samples, extensive geochemical analyses were performed. The brine trapper consisted of an outer PVC cylinder pierced by a regularly spaced windows and a series of inner delrin ${ }^{\circledR}$ plugs connected by a stainless steel rod. Each end of the plugs was fitted with an O-ring bore seal. The spaces between the plugs formed a series of internal compartments, each having a volume of about $200 \mathrm{~mL}$. The compartments were open to the environment when aligned with the windows and closed when the plugs were aligned with the windows. Each sampling compartment 
was fitted with a pressure-relief valve and a sampling port (Fig. 2a). On the surface and during descent to the bottom, the compartments were in the open position. On the seafloor, the trapper was lowered vertically into the brine using a hydraulically actuated lever mounted on the side of the submersible (Fig. 2b). The top chamber was visually aligned in the overlying seawater above the brine-seawater interface. Once the trapper was in position, chambers were permitted to equilibrate, and then a hydraulic actuator pulled on the connecting rod to align the plugs with the windows and seal the compartments. The trapper was removed from the brine and positioned horizontally along the side of the submersible for return to the surface.

When the submersible was safely on deck, the brine trapper was removed and sampled. Because of the length $(3 \mathrm{~m})$ of the instrument, sampling was done on deck in the shade within $30 \mathrm{~min}$ of return to the surface. For each chamber, the sampling valve was opened and two samples of the venting gas were collected and transferred to a helium-purged, evacuated serum bottle $(20 \mathrm{~mL})$. After collecting gas samples, the overpressure in the chamber was relieved slowly. Next, the brine fluids were collected by attaching a length of argon-purged tubing to the sampling port and collecting the fluid from each chamber into an argon-purged 60-mL syringe. The brine fluid was transferred from the syringe into an argon-purged, clean (3X 10\% $\mathrm{HCl}$ washed and milliQ ${ }^{\circledR}$ water rinsed) $500 \mathrm{~mL}$ PETG sampling bottle. Then, the headspace of the sampling bottle was purged with argon and bottles were capped and transferred to a $4^{\circ} \mathrm{C}$ cold room for processing. Sub-samples for geochemical analyses were filtered $\left(0.2 \mu \mathrm{m}\right.$ Millex ${ }^{\circledR}$ syringe-tip filter) before dispensing aliquots into vials for various analyses.

\subsection{Geochemistry}

The concentration of dissolved hydrocarbons $\left(\mathrm{C}_{1}-\mathrm{C}_{5}\right)$ in the venting gas from the compartments of the brine trapper was determined by injecting a $0.25 \mathrm{cc}$ sub-sample into a Shimadzu gas chromatograph equipped with a Hayes-Sep- ${ }^{\circledR}$ column $(2 \mathrm{~m})$, which separated $\mathrm{C}_{1}-\mathrm{C}_{5}$ hydrocarbons as a programmed temperature ramp was applied, and a flame ionization detector, which quantified sample signals (Joye et al., 2004). Certified standard gas mixtures $\left(10 \% \mathrm{CH}_{4}\right.$ and a $\mathrm{C}_{1}$ $\mathrm{C}_{5}$ mix in a balance of $\mathrm{He}$ ) were used to calibrate the $\mathrm{GC}$ signals. Analytical precision was between 1.5 and $4 \%$. The carbon isotopic composition of methane was determined using a gas chromatograph coupled to an isotope ratio monitoring mass spectrometer (Popp et al., 1995). Appropriate blanks and internal standards were run routinely in the following geochemical analyses and sample concentrations were determined by comparison to a curve generated using certified standards.

Sub-samples $(1.5 \mathrm{~mL})$ for the determination of dissolved anion (sulfate, $\mathrm{SO}_{4}^{2-}$, and chloride, $\mathrm{Cl}^{-}$) and cation (magne-
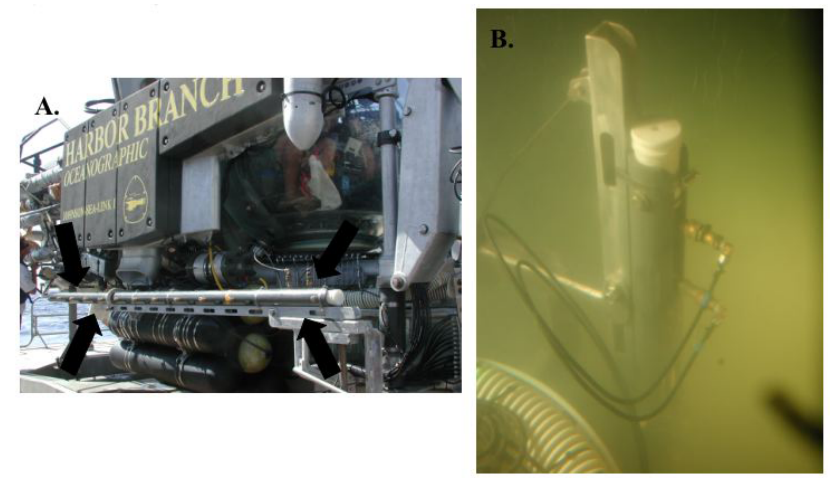

Fig. 2. Photos of the brine trapper used to collect 3-m vertical profiles in deep-sea brines. (A) The brine trapper was positioned along the side of the Johnson Sea Link (note black arrows) and was lowered vertically into the brine to collect a profile from the overlying seawater into the core of the brine (B).

sium, $\mathrm{Mg}^{2+}$, calcium, $\mathrm{Ca}^{2+}$, sodium, $\mathrm{Na}^{2+}$ and potassium, $\mathrm{K}^{+}$) concentration were preserved via acidification with ultrex $\mathrm{HNO}_{3}\left(100 \mu \mathrm{L} \mathrm{HNO}_{3}\right.$ per mL sample). Major ion concentrations were quantified on a Dionex ${ }^{\circledR}$ DX5000 ion chromatograph after dilution by either 1:100 (for concentrations $>2 \mathrm{mM}$ ) or 1:10 (for concentrations $<2 \mathrm{mM}$ ). For $\mathrm{SO}_{4}^{2-}$ analysis, precision was $1.5 \%$ for concentrations $>2 \mathrm{mM}$ and $5-7 \%$ for $<2 \mathrm{mM}$. Precision for other ions was typically better than $1 \%$. Dissolved reduced iron $\left(\mathrm{Fe}^{2+}\right)$ concentration was determined in an aliquot of the acidified major ion sample using the Ferrozine colorimetric method (Stookey, 1979). Dissolved inorganic carbon concentration was determined using a Shimadzu TOC5000 ${ }^{\circledR}$ infrared analyzer. Samples for the determination of dissolved nutrients were filter-sterilized and stored at $4^{\circ} \mathrm{C}$ until analysis on board the ship. Nitrate $\left(\mathrm{NO}_{3}^{-}=\right.$nitrate plus nitrite $)$, phosphate $\left(\mathrm{PO}_{4}^{3-}\right)$ and silicate $\left(\mathrm{H}_{2} \mathrm{SiO}_{4}^{2}\right)$ concentrations were determined using standard methods on a Lachat 3-channel QuikChem ${ }^{\circledR} 8000$ autoanalyzer. Precision of these analyses was about $2 \%$. Ammonium $\left(\mathrm{NH}_{4}^{+}\right)$was analyzed immediately on board ship using the indo-phenol colorimetric method (Solaranzo, 1969) with an analytical precision of $2 \%$. Brine $\mathrm{pH}$ was determined using a high impedance electrometer that was standardized with $\mathrm{pH} 4$ and 7 buffers. The relative amount (\%) of suspended matter was determined by filtering a known volume of brine and determining the volume of fluid compared to the amount of solid phase material.

The relative concentration of geochemical constituents in the brine fluids relative to the overlying seawater was determined by averaging the concentration of a constituent in the five deepest brine trapper samples. That average value was then divided by the concentration observed in the overlying bottom water. Enrichment of a constituent in the brine relative to the bottom water is reflected by values $>1$ while depletion in the brine relative to seawater is reflected by values 
Table 1. Dissolved methane concentration in parts per million ( $\mathrm{ppm}$ ) and \% of total hydrocarbons as methane (in parenthesis) over depth in the brine pool and mud volcano in 1998 and 2002. [n.d. = no data, chambers were too over-pressured for sample collection; *leakage in the chamber during ascent or dilution during sample collection]. For reference, the equilibrium methane concentrations at in situ temperature

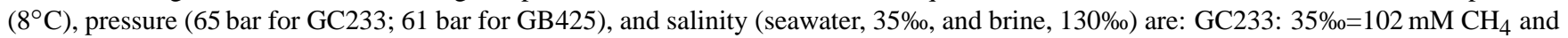
$130 \%$ o $=53 \mathrm{mM} \mathrm{CH}_{4}$ and GB425: $35 \%$ o $=95 \mathrm{mM} \mathrm{CH}_{4}$ and $130 \%$ o $=50 \mathrm{mM} \mathrm{CH}_{4}$.

\begin{tabular}{ccccc}
\hline Site/Date: & GC233 1998 & GC233 2002 & GB425 1998 & GB425 2002 \\
\hline Depth (cm) & $\mathrm{CH}_{4} \mathrm{ppm}(\%)$ & $\mathrm{CH}_{4} \mathrm{ppm}(\%)$ & $\mathrm{CH}_{4} \mathrm{ppm}(\%)$ & $\mathrm{CH}_{4} \mathrm{ppm}(\%)$ \\
\hline 0 & $765385(99.9)$ & $8151(99.9)$ & n.d. & $151440(97.1)$ \\
23 & $623885(99.9)$ & $135996(99.9)$ & n.d. & $539242(96.7)$ \\
46 & $315908(99.9)$ & $599541(99.9)$ & n.d. & $1033369(96.4)$ \\
68 & $806065(99.9)$ & $563692(99.8)$ & n.d. & $951999(95.2)$ \\
91 & $451206(99.9)$ & $867947(99.9)$ & n.d. & $943837(96.4)$ \\
114 & $944533(99.9)$ & $817883(99.9)$ & n.d. & $1020328(97.6)$ \\
137 & $999515(99.9)$ & $1012613(99.9)$ & $916588(98.3)$ & $917553(96.2)$ \\
160 & $979935(99.9)$ & $982982(99.9)$ & $775103(98.3)$ & $* 521317(94.1)$ \\
182 & $992897(99.9)$ & $918422(99.8)$ & $868131(98.3)$ & $927599(96.8)$ \\
205 & $784305(99.9)$ & $* 354070(98)$ & n.d. & n.d. \\
\hline
\end{tabular}

$<1$. We refer to this term as the "relative concentration" but it is comparable to the "enrichment factor" (Ef) presented by Aharon et al. (1992b).

\section{Results}

\subsection{Geologic and Geophysical setting}

Brine and gas seepage occurred at both sites but oil seepage was only observed at GB425. Both brines were thermally and geochemically stratified but visual observations and temperature records suggest that, on average, fluid flow at GB425 exceeded that at GC233. Laser line scan and subbottom data revealed the geologic nature of both sites (Figs. 3 and 4$)$. The GC233 site is a small brine pool $\left(190 \mathrm{~m}^{2}\right)$ situated at a depth of $650 \mathrm{~m}$ (MacDonald et al., 1990; Fig. 3). A laser line scan mosaic (Fig. 3a) was geo-rectified in the ERMAPPER ${ }^{\circledR}$ software environment (MacDonald et al., 2000; Sager et al., 2003). The GC233 brine pool is situated on a mound, which is elevated 6 to $8 \mathrm{~m}$ above the surrounding seafloor and has a basal diameter of approximately $100 \mathrm{~m}$ (Fig. 3). The fluid filling the pool had a salinity of $130 \%$ and was supersaturated with gas (Table 1). Added density due to the excess salt maintained the brine as a distinct fluid in the pool but the brine mixes with seawater by molecular and eddy diffusion.

Subbottom records revealed considerable complexity at this site. On the flanks of the mound, indurate layers underlie layers with a weak seismic reflection (Fig. 3c), suggested surface flows of loosely consolidated material over hardened ground. A narrow dike, raised about $25 \mathrm{~cm}$, formed a rim that surrounds three sides of the pool outside of the mussel bed. The mussels appeared as a layer distinct from the brine, which formed a level reflector. Below the brine, sediments were homogeneous and contained a large, irregular reflector near the bottom of the record. The most regular subbottom features were a sequence of layers buried under the presentday mound. Distances between these layers were greatest in the center of the mound and least around the edges. The deepest layer formed a funnel shaped base to the outline of the mound.

Temperature profiles collected in 1991, 1992 and 1998 (Fig. 5a) showed a sharp interface between brine and seawater and $\mathrm{a} \sim 1-\mathrm{m}$ thick layer in which the temperature was elevated about $1.5^{\circ} \mathrm{C}$ above ambient bottom water temperature. Below this depth, a thermocline extended over $\sim 1.5 \mathrm{~m}$ as the temperature increased to about $17^{\circ} \mathrm{C}$. Temperature was essentially stable at depths greater than $3 \mathrm{~m}$ below this depth. Visually, the mixed layer was often clear, although refraction made it appear darker than seawater. In some instances the seawater-brine interface was slightly turbid, suggesting that in situ processes, like sulfide oxidation, may culminate in the precipitation of elemental sulfur in the vicinity of the seawater-brine interface. Within and below the thermocline, the brine contained a high concentration of suspended solids (ca. $50 \%$ by volume; data not shown). The $\mathrm{pH}$ of the upper brine was about 6.4 while the $\mathrm{pH}$ of the lower brine was 6.8 (data not shown). Similar temperature profiles over a 7year period indicate the recent stability of the pool's density structure.

At the time of CTD sampling, seepage at GC233 was dominated by brine and free and dissolved gases (MacDonald et al., 1990). Continuous discharge of gas through the brine leads to saturation with dissolved methane, which serves as a source of energy for mussels with methanotrophic symbionts found along the edges of the pool (Nix et al., 1995). 

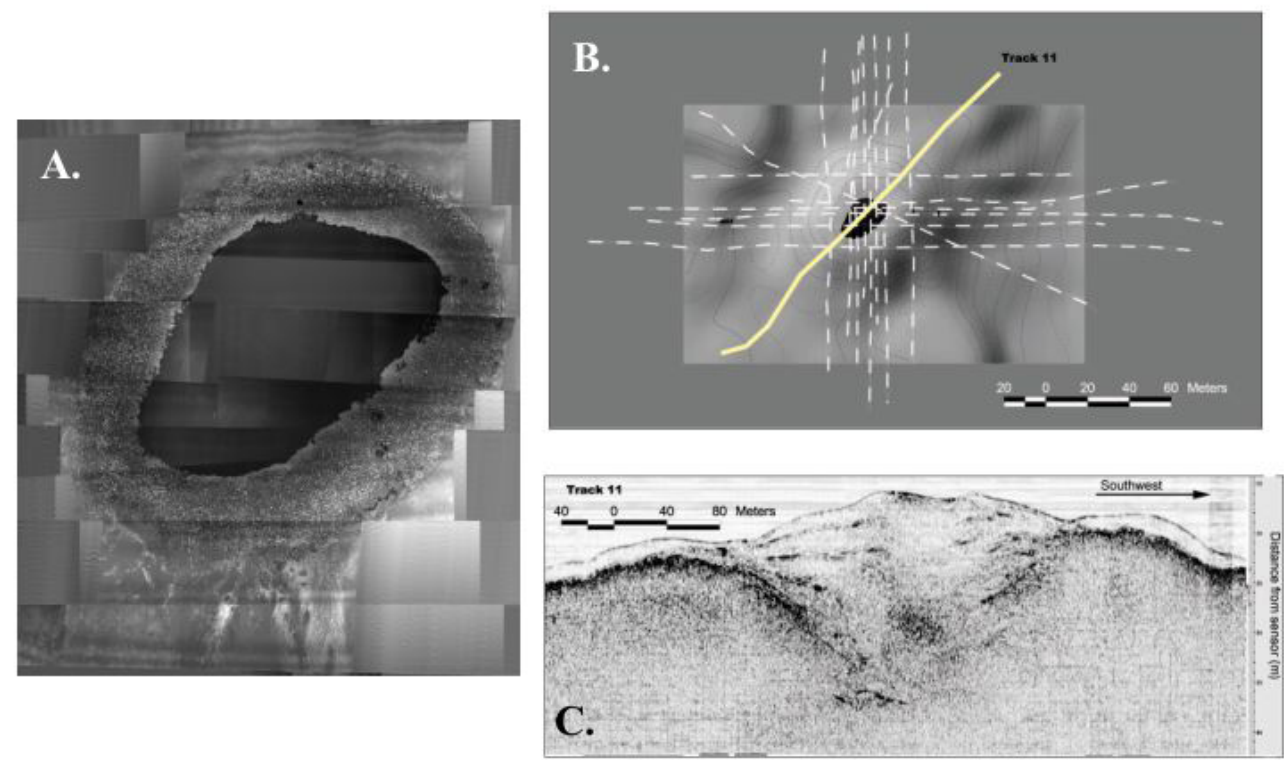

Fig. 3. Laser line scan mosaic and subbottom profile for the GC233 brine pool. (A) Laser-line scan mosaic showing the surface of the brine pool and the surrounding rim of mussels. (B) Plan of site showing trackline. (C) Subbottom record from Track 11 taken along southwest to northeast track. Water depth of submarine was held constant (within $<1 \mathrm{~m}$ ) along trackline, so the bottom profile is accurate. Data collected in 1997 and 1998.

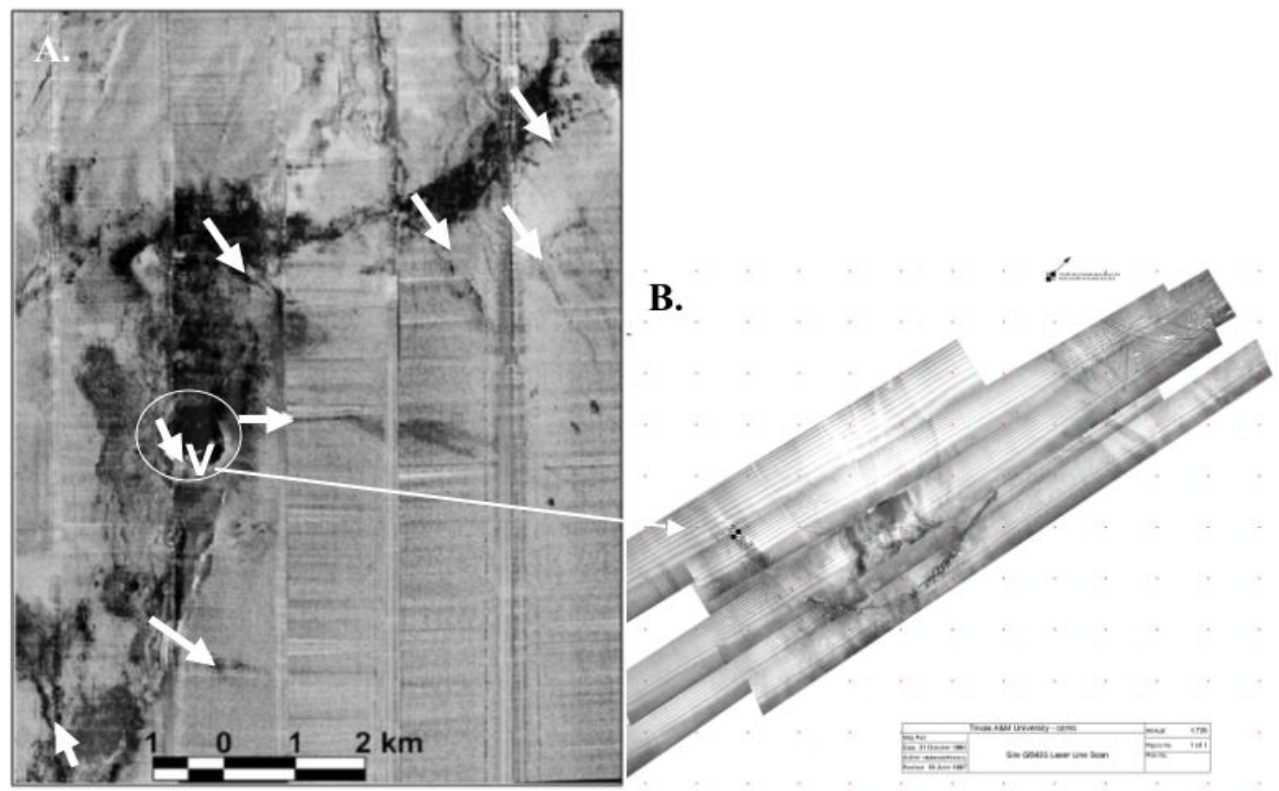

Fig. 4. (A) Side scan mosaic of the GB425 site (adapted from MacDonald et al., 2000). The white arrows on the side-scan mosaic denote major mud vents and the mud volcano is the large pool in the center right noted by "V" and the white circle. (B) Laser line scan mosaic of southern rim of the mud-filled crater, showing location of M1 sampling station (grid points are at $10 \mathrm{~m}$ centers). Mussel beds are restricted to southwestern (upslope) end of pool. Data collected in 1997 and 1998.

Patchy mats of giant sulfur bacteria, such as Beggiatoa, Thioploca, and Thiomargarita, covered the sediments adjacent to the mussel beds (Larkin et al., 1994; Nikolaus et al., 2003; Kalanetra et al., 2005) (Figs. 6a, b). At the southern end of the pool, visible flows of brine were apparent and these flows were underlain by black, highly reduced sediment that was colonized by mats of giant sulfur bacteria. Other brine sites experience much more vigorous but episodic brine eruptions; such a site is the GB425 mud volcano. 

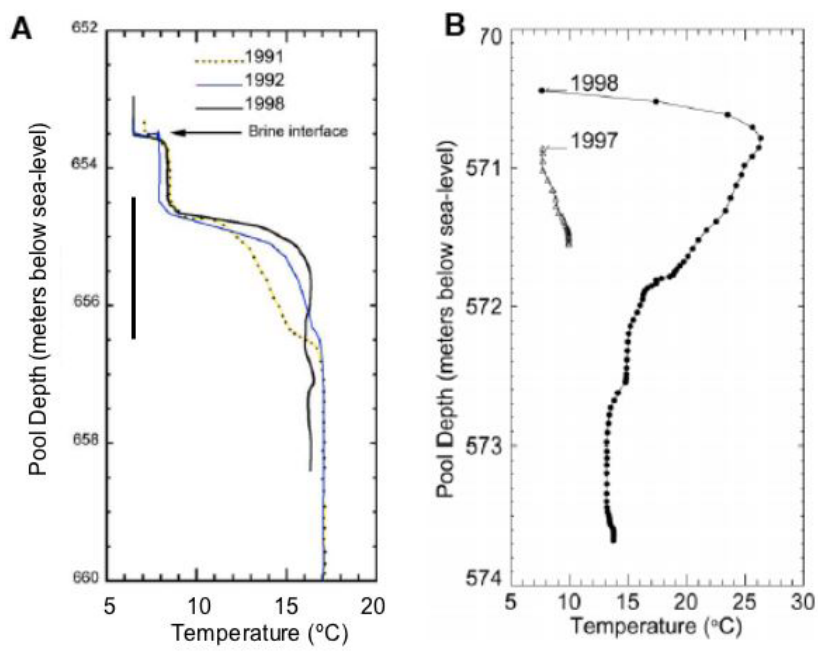

Fig. 5. Temperature profiles from GC233 brine pool (A) and the GB425 mud volcano (B) collected between 1991 and 1998. Dotted lines mark seawater-brine interfaces. Note the difference in scale between the depth axes on the two panels. The solid horizontal line in panel (A) notes the approximate sampling range of the brine trapper.

The GB425 site lies on the western edge of the Auger basin (MacDonald et al., 2000; Fig. 4), an intraslope basin that contains economically significant hydrocarbons in the Auger, Cardamom, and Macaroni fields and is bordered to the west by tabular salt bodies (McGee et al., 1993; Sager et al., 2003). The GB425 mud volcano is situated at a small, active diatreme on the southern margin of a flat-topped mound located mid-way along a major fault. A tension-leg platform installed at Auger Field is producing from an estimated 100 million barrels of extractable oil (Shew et al., 1993), but large quantities of pressurized fluid have evidently escaped through anticline faults along the flanks of the salt diapir along the basin margin. Fluids migrating up these faults disturb surface sediments due to the formation of carbonate nodules, oil and gas pockets, and biogenic debris. Sediment cores from the area contained high-molecular weight hydrocarbon and thermogenic gas hydrate (MacDonald et al., 2000). Active venting of brine, free and dissolved gases, and high molecular weight hydrocarbons sustains an expulsion crater from which gas and fluidized mud streams are frequently visible (MacDonald et al., 2000). The sediments adjacent to the south of the diatreme support chemosynthetic mussel communities and mats of free-living giant sulfur bacteria (Figs. 6c, d), however, the distribution of mussels and microbial mats is more patchy here than at GC233.

The GB425 pool is physically larger than the GC233 pool and supports a high rate of gas discharge and flows of fluidized muds (MacDonald et al., 2000). The brine consisted of fine clay suspended in brine having a salinity of $133 \%$. The suspended sediment load is at least $65 \%$ by volume (data
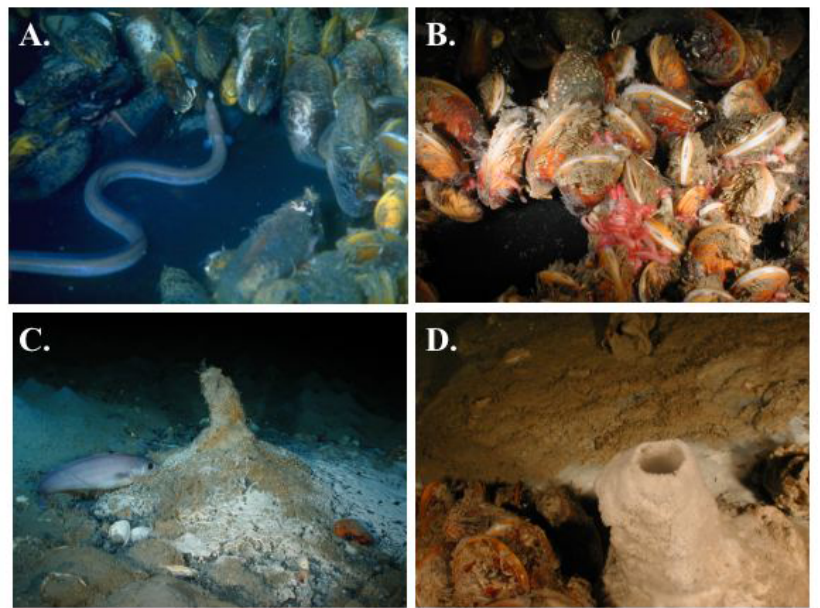

Fig. 6. Images showing bottom features near the GC233 brine pool $(\mathrm{A}, \mathrm{B})$ and the GB425 mud volcano $(\mathrm{C}, \mathrm{D})$. A ring of mussels surrounds the GC233 brine pool and eels frequently skim the brine surface (A). Numerous associated fauna cohabitate the mussel bed, such as a variety of amphipods, crabs and polychaete worms (B). White bacterial mats $(\mathbf{C})$ are abundant along the edge of the mud volcano as are barite chimneys (D). All photos were taken in July 2002 .

not shown) and the brine $\mathrm{pH}$ was about 7.4. A temperature profile through the brine obtained in 1997 showed only slight temperature elevations in the brine temperature relative the overlying seawater. However, in 1998, a maximum temperature of $26.2^{\circ} \mathrm{C}$ was observed less than $0.5 \mathrm{~m}$ below the interface (Fig. 5b). The surface level of the brine had increased significantly between 1997 and 1998, providing additional evidence of vigorous flow and underscoring the temporal variability of the magnitude and volume of brine flow here.

\subsection{Geochemistry}

A comparison of depth profiles of geochemical parameters between the brine pool and mud volcano underscored fundamental differences between the two sites. Our sampling protocol ensured that the uppermost chamber contained seawater from just above the brine-seawater interface, which we used as our zero depth reference. The geochemistry of the uppermost seawater sample was similar at both sites. Both brines contained large amounts of gas, primarily methane (Table 1). At the brine pool, methane accounted for $99.9 \%$ of C1-C5 hydrocarbons and the carbon isotopic composition of the methane $\left(\delta^{13} \mathrm{C}_{-} \mathrm{CH}_{4}\right)$ was $-66 \%$. At the mud volcano, methane accounted for 94 to $98 \%$ of C1-C5 hydrocarbons and the $\delta^{13} \mathrm{C}_{-} \mathrm{CH}_{4}$ was $-60 \%$.

Both brines contained similar concentrations of $\mathrm{Na}^{+}$ $(\sim 1800 \mathrm{mM})$ and $\mathrm{Cl}^{-}(2100 \mathrm{mM})$, little to no $\mathrm{SO}_{4}^{2-}(0$ to $1 \mathrm{mM}$ ), and exhibited a slight decrease in $\mathrm{Mg}^{2+}$ concentration with depth into the brine (Fig. 7). In the brine pool, the 

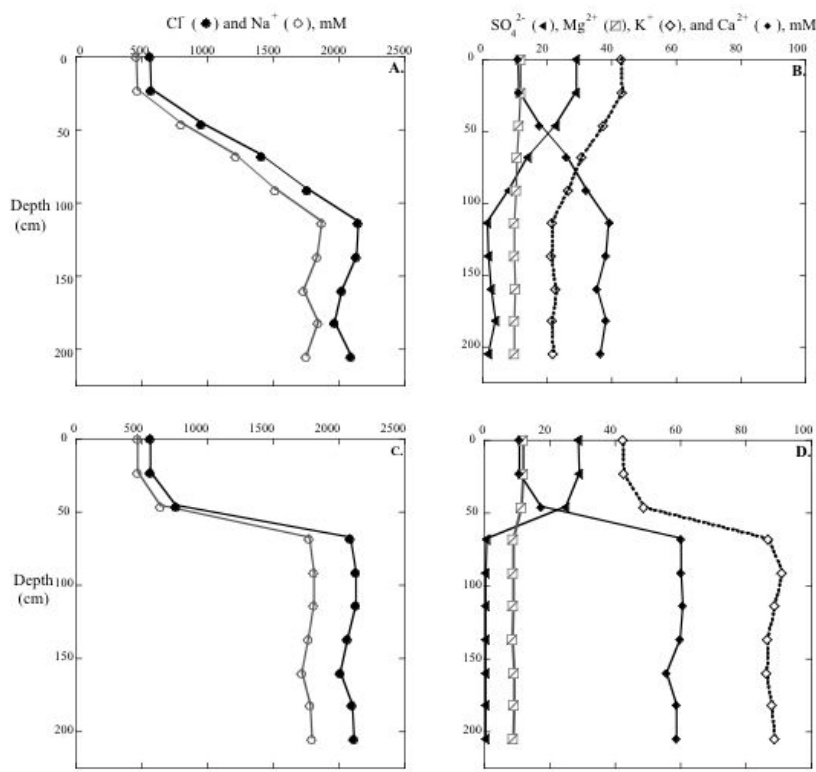

Fig. 7. Depth profiles of major ion concentration in the GC233 brine pool $(\mathbf{A}, \mathbf{B})$ and in the GB425 mud volcano $(\mathbf{C}, \mathbf{D})$ (data collected in July 2002).

transition between the overlying seawater and the brine occurred gradually between 30 and $150 \mathrm{~cm}$ (Figs. 7a and b). In the mud volcano, the transition from overlying seawater to the brine was abrupt, with steep gradients observed between $\sim 20$ and $60 \mathrm{~cm}$ (Figs. $7 \mathrm{c}$ and d). Calcium concentrations increased with depth in both brines but reached higher concentrations in the mud volcano. Potassium concentration decreased with depth in the brine pool but increased with depth in the mud volcano (Figs. $7 \mathrm{~b}$ and d). Plots of salts versus sodium concentration for the two brines suggested different end-member compositions (Fig. 8). The relative concentration of various constituents in bottom water versus the brine fluids is given in Table 2 and a comparison of the geochemistry of the brines described here to other deep-sea brines is provided in Table 3.

Nitrate concentrations were high in the overlying seawater and decreased with depth in the brine (Fig. 9). In the brine pool, $\mathrm{NO}_{3}^{-}$versus $\mathrm{Cl}^{-}$concentration plots showed conservative mixing between the two end-member fluids (data not shown). In the mud volcano, the transition between the seawater and brine was abrupt, but a plot of $\mathrm{NO}_{3}^{-}$versus $\mathrm{Cl}^{-}$ concentration for 0 and $68 \mathrm{~cm}$ samples suggested a possible $\mathrm{NO}_{3}^{-}$sink in the 23 and $46 \mathrm{~cm}$ samples (data not shown). Phosphate concentrations were somewhat elevated in the brines relative to seawater but concentrations varied significantly. Silicate concentrations increased from $40 \mu \mathrm{M}$ in the overlying seawater to over $200 \mu \mathrm{M}$ in the brine (Fig. 9). Ammonium concentrations increased from $\sim 0.5 \mu \mathrm{M}$ in the overlying seawater to between 12 (brine pool) and 8 (mud volcano) $\mathrm{mM}$ at depth in the brine (Fig. 9). Concentrations of
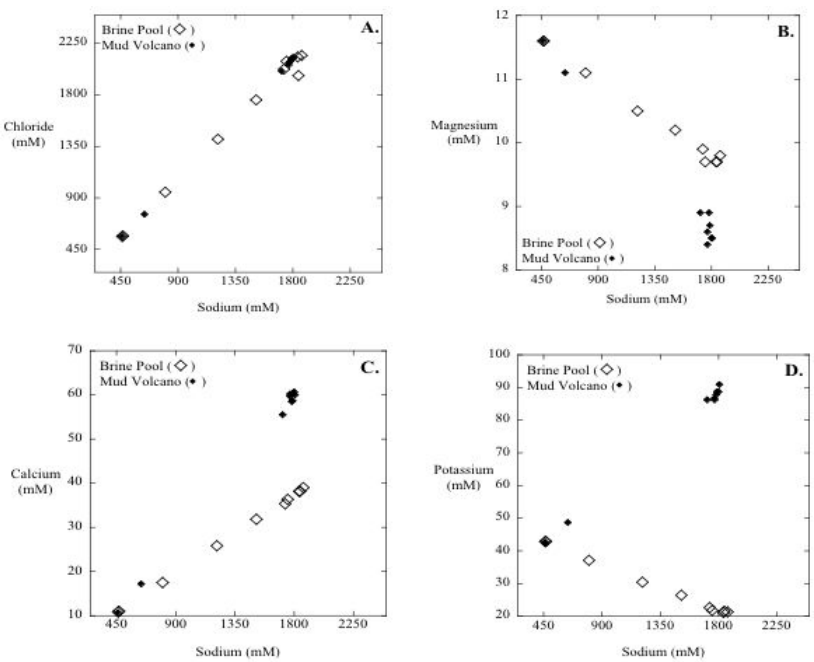

Fig. 8. Plots of chloride (A), magnesium (B), calcium (C) and potassium (D) versus sodium for the GC233 brine pool and GB425 mud volcano (data collected in July 2002).

Table 2. Relative concentration of constituents in bottom water versus brine fluids for samples collected in July 2002. Units of concentration for major ions ( $\mathrm{Na}, \mathrm{K}, \mathrm{Mg}, \mathrm{Ca}, \mathrm{Cl}, \mathrm{SO} 4$ and $\mathrm{HCO} 3$ ) are $\mathrm{mM}$ and units of concentration for nutrients and DOC are $\mu \mathrm{M}$. Values in bold reflect enrichment relative to bottom water, values in italics reflect depletion relative to bottom water, and bold underline values denote differences between the two brines.

\begin{tabular}{lccccc}
\hline \multicolumn{2}{c}{ Bottom Water } & \multicolumn{2}{c}{ GB425 } & \multicolumn{2}{c}{ GC233 } \\
Constituent & Conc. & Conc. & Rel. Conc. & Conc. & Rel. Conc. \\
\hline $\mathrm{Na}^{+}$ & 462.65 & 1771.0 & $\mathbf{3 . 8}$ & 1805.0 & $\mathbf{3 . 9}$ \\
$\mathrm{K}^{+}$ & 42.55 & 87.5 & $\underline{\mathbf{2 . 1}}$ & 21.6 & 0.5 \\
$\mathrm{Ca}^{2+}$ & 10.7 & 58.6 & $\underline{\mathbf{5 . 5}}$ & 37.4 & $\mathbf{3 . 5}$ \\
$\mathrm{Mg}^{2+}$ & 11.6 & 8.7 & 0.75 & 9.8 & 0.8 \\
$\mathrm{Cl}^{-}$ & 561.85 & 2081.9 & $\mathbf{3 . 7}$ & 2073.0 & $\mathbf{3 . 7}$ \\
$\mathrm{SO}_{4}^{2-}$ & 28.75 & 0.3 & 0.01 & 2.2 & 0.08 \\
$\mathrm{HCO}_{3}^{-}$ & 2 & 4.2 & $\mathbf{2 . 1}$ & 1.6 & 0.8 \\
$\mathrm{NO}_{3}^{-}$ & 31.5 & 0.9 & 0.03 & 0.9 & 0.03 \\
$\mathrm{NH}_{4}^{+}$ & 65 & 7600 & $\mathbf{1 1 6 . 9}$ & 10863 & $\mathbf{1 6 7 . 1}$ \\
$\mathrm{HPO}_{4}^{2-}$ & 2.1 & 2.1 & 1 & 2.1 & 1 \\
$\mathrm{H}_{2} \mathrm{SiO}_{4}^{2-}$ & 23.1 & 206.4 & $\mathbf{8 . 9}$ & 170.9 & $\mathbf{7 . 4}$ \\
$\mathrm{DOC}^{2-}$ & 387.5 & 2326.8 & $\mathbf{6}$ & 2332 & $\mathbf{6}$ \\
\hline
\end{tabular}

reduced iron $\left(\mathrm{Fe}^{2+}\right)$ were higher at $\mathrm{GC} 233$ while concentrations of DIC were higher at GB425 (Fig. 10).

\section{Discussion}

We used an integrated approach to evaluate the dynamics and biogeochemical signatures of two brine-dominated cold seeps along the continental slope in the Gulf of Mexico. Our data support two major conclusions: 1) Though fluid, gas 
Table 3. Geochemical composition of the GC233 and GB425 brines (data from 2002) and other brines from the Gulf of Mexico, Mediterranean, Black Sea and Red Sea. Salinity $=\%$; all concentrations in $\mathrm{mM}$ except $\mathrm{Fe}^{2+}$ which is in $\mu$ M. n.d. denotes "no data".

\begin{tabular}{|c|c|c|c|c|c|c|c|c|c|c|c|}
\hline Site ID & Salinity & {$\left[\mathrm{Cl}^{-}\right]$} & {$\left[\mathrm{Na}^{+}\right]$} & {$\left[\mathrm{K}^{+}\right]$} & {$\left[\mathrm{Ca}^{2+}\right]$} & {$\left[\mathrm{Mg}^{2+}\right]$} & {$\left[\mathrm{SO}_{4}^{2-}\right]$} & {$\left[\mathrm{H}_{2} \mathrm{~S}\right]$} & {$\left[\mathrm{Fe}^{2+}\right]$} & {$\left[\mathrm{NH}_{4}^{+}\right]$} & Reference \\
\hline GC233 & 121 & 2092 & 1751 & 22 & 36 & 9.7 & $<1$ & 0.002 & 92 & 11 & This study \\
\hline GB425 & 130 & 2114 & 1790 & 89 & 59 & 8.7 & $<1$ & 0.004 & 24 & 7.6 & This study \\
\hline Bottom water $b$ & 34 & 564 & 462 & 43 & 11 & 11 & 29 & $\sim 0$ & $\sim 0$ & 0.1 & This study \\
\hline Orca Basin ${ }^{a, b}$ & 258 & 5,000 & n.d. & n.d. & 32 & n.d. & 47 & 0.6 & n.d. & 0.5 & Shokes et al. (1977) \\
\hline Orca Basin ${ }^{a, b}$ & 250 & 4450 & 4240 & 17.2 & 29 & 42.4 & 20 & 0.025 & 30 & 0.5 & Van Cappellen et al. (1998) \\
\hline Urania Basin ${ }^{a, c}$ & 200 & 2830 & n.d. & n.d. & 34 & n.d. & 85 & $8.6-11$ & n.d. & n.d. & Sass et al. (2001) \\
\hline Libeccio Basin ${ }^{a, c}$ & 321 & 5333 & n.d. & n.d. & 21 & n.d. & 99 & 1.7 & n.d. & 3 & Sass et al. (2001) \\
\hline Tyro Basin ${ }^{a, c}$ & n.d. & 5350 & n.d. & n.d. & 34 & n.d. & 49 & 2.1 & n.d. & 1.2 & Sass et al. (2001) \\
\hline Napoli $c, d$ & 82 & 1380 & 1347 & 8.1 & 8.4 & 33.9 & 28.4 & 3.5 & n.d. & n.d. & Charlou et al. (2003) \\
\hline Nadir $c, d$ & 120 & 1979 & 1884 & 7.2 & 22.2 & 27.9 & 37.8 & 5.8 & n.d. & n.d. & Charlou et al. (2003) \\
\hline Urania $c, d, e$ & 70 & 1075 & 922 & 26.6 & 16.8 & 82.3 & 44.7 & 1.6 & n.d. & n.d. & Charlou et al. (2003) \\
\hline Bottom water ${ }^{c}$ & 35 & 600 & 492 & 11.2 & 11 & 56 & 31 & 0 & n.d. & n.d. & Charlou et al. (2003) \\
\hline Dvurenchenskii $d, e, f$ & 50 & 835 & 730 & 4.3 & 30 & 18.3 & 0 & 0 & n.d. & 20 & Aloisi et al. (2004) \\
\hline Shaban Deep \#3 ${ }^{a, g}$ & 242 & 4358 & 4408 & 44 & 20 & 77 & n.d. & n.d. & 122 & n.d. & Eder et al. (2002) \\
\hline Shaban Deep \#12 ${ }^{a, g}$ & 220 & 4361 & 3953 & 39 & 19 & 74 & n.d. & n.d. & 108 & n.d. & Eder et al. (2002) \\
\hline Atlantis-II ${ }^{a, h}$ & 126 & 2000 & n.d. & n.d. & n.d. & n.d. & 0 & 0 & 0 & n.d. & Schmidt et al. (2003) \\
\hline Discovery ${ }^{a, h}$ & 252 & 4000 & n.d. & n.d. & n.d. & n.d. & 0 & 0 & 0 & n.d. & Schmidt et al. (2003) \\
\hline Kebrit $a, h$ & 252 & 4000 & n.d. & n.d. & n.d. & n.d. & 30 & 0.4 & 0 & n.d. & Schmidt et al. (2003) \\
\hline
\end{tabular}

${ }^{a}$ Brine basin or pool, ${ }^{b}$ Gulf of Mexico, ${ }^{c}$ Mediterranean, ${ }^{d}$ Mud Volcano, ${ }^{e}$ brine-seawater interface, ${ }^{f}$ Black Sea, ${ }^{g}$ Red Sea, two stations reported, $3 \& 12,{ }^{h}$ Red Sea
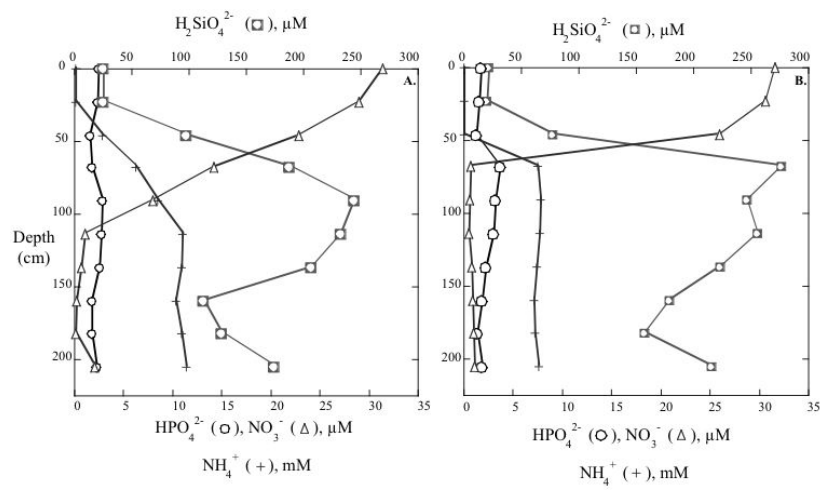

Fig. 9. Depth profiles of nutrient $\left(\mathrm{H}_{2} \mathrm{SiO}_{4}^{2-}, \mathrm{NO}_{3}^{-}, \mathrm{HPO}_{4}^{2-}\right.$, and $\mathrm{NH}_{4}^{+}$) concentrations in the GC233 brine pool (A) and the GB425 mud volcano (B) (data collected in July 2002).

and mud discharge rates at the two sites differed, both sites were likely sources of methane, ammonium, silicate, and in the case of the GB425 site, brine and oil, to the surrounding environment. Variations in fluid flow rates resulted in different mixing regimes and/or intensities in the two brines and this difference likely contributed to the observed variations in geochemistry. 2) While the sodium and chloride content of brines from the brine pool and mud volcano were similar, concentrations of other major ions differed between the two sites, which suggests different sources and/or sinks for dom-
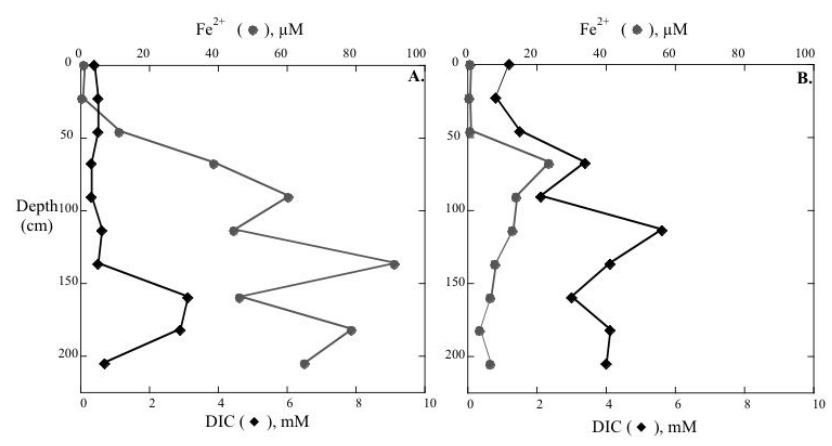

Fig. 10. Concentrations of reduced iron $\left(\mathrm{Fe}^{2+}\right)$ and dissolved inorganic carbon (DIC) in the GC233 brine pool (A) and the GB425 mud volcano (B) (data collected in July 2002).

inant ions in the brine fluids. Below, we present a model to explain the patterns of fluid flow observed at these two brinedominated cold seeps.

\subsection{Fluid discharge at brine-dominated cold seeps}

At both sites, central pools of fluidized mud and hypersaline brine had core temperatures that were $\geq 10^{\circ} \mathrm{C}$ warmer than ambient seawater (Fig. 5). While spatio-temporal variation in seepage rates apparently exists at both sites (MacDonald et al., 2000), fluid discharge, albeit low at times, occurs continuously. The rate of fluid discharge influenced the magnitude 
of stratification within the brine, which was apparent in thermal and geochemical profiles over depth (Fig. 5). Based on the data presented here, previous studies, and our extensive documentation of bubble plumes and brine levels at both sites, we conclude that the brine pool at the GC233 site has been contained largely within the pool banks over a decadal timescale, though some flow of brine over the southern rim of the pool does occur, and that this brine maintains a consistent internal temperature stratification. In contrast, the brine pool at GB425 is a mud-volcano type formation in which fluid flux from deep sources generates episodic and significant temperature fluctuations within the pooled brine, vigorous oil and gas discharge into the water column, and frequent mud flow over the pool edges (MacDonald et al., 2000).

At GC233, gas discharge was limited to a sparse stream of small bubbles that emanated steadily from the center and northern edge of the pool. CTD temperature profiles showed a meter-thick mixing zone between brine and the overlying seawater. A similar meter-thick mixing zone was apparent in the salt profiles (Figs. 7, 8). The salt diapir beneath the GC233 brine pool lies within $500 \mathrm{~m}$ of the seafloor (MacDonald et al., 1990; Reilly et al., 1996). At the GB425 site, strong seismic reflectors at 50 and $150 \mathrm{~ms}$ twt (two way travel time) beneath the mud volcano suggest the presence of a very shallow salt body (Sager et al., 2003). No such reflectors appear in the 2-D lines from GC233 (Sager et al., 2003). The shallow depth of the salt body beneath the GB425 site may contribute to the enhanced fluid flow observed at this site (discussed further below).

The elevation of the GC233 mound, sediment slides and bacterial mats on the down slope (southern) end of the pool, and a raised dike around the upslope (northern) edge of the pool, provide evidence that the pool was excavated by a vigorous discharge of fluid (Fig. 3). The persistence of a mussel community, developed in the present day to a continuous band that completely surrounds the pool on the level margins of the crater (Fig. 3), is strong evidence that conditions have favored chemosynthetic communities for an extended period of time. The probable age of the larger seep mussels in this population exceeds $100 \mathrm{y}$ (Nix et al., 1995), which suggests that the lifetime of the pool is on the order of hundreds of years. The extensive mussel community requires long-term stability of the level of brine filling the pool because the brine is anoxic in addition to being hypersaline; it would be fatal for the mussels to be submerged in the anoxic brine.

At the GB425 site, active fluid expulsion is restricted to a 50-m wide, sub-circular crater on the southwestern edge of the summit, which is one of two such vents on the mound (Fig. 4). Fine, fluidized mud overflows the northeastern margin of the crater and moves down the southern flank of the mound in localized streams that are visible as ribbons of brine flowing along the seafloor (MacDonald et al., 2000). The particle rich hypersaline brine is anoxic and is supersaturated with methane (Table 1). Beds of the seep mussel rim the southern edge of the crater (Figs. 6c, d). Sampling of this site over the past eight years has documented substantial variations in flow regimes. In 1997, visual observations indicated only minor discharges of gas and oil. In 1998, however, a continual stream of small gas bubbles and drops of oil emanated from the central diatreme, while bursts of larger bubbles, oil drops, and suspended sediment periodically vented from the surrounding mud. Similar active and widespread venting was observed during submersible dives conducted in 2002. Such large, continuous eruptions lead to conspicuous sea surface oil slicks that can be mapped easily using Synthetic Aperture Radar (SAR; cf. MacDonald et al., 2000).

Evidence for discontinuous fluid discharge at this site was apparent in a temperature record obtained from a thermistor suspended at the shallow edge of the mud volcano between 1997 and 1998 (MacDonald et al., 2000). The temperature at the brine-seawater interface fluctuated between 6.9 and $48.2^{\circ} \mathrm{C}$, and had an average temperature of $26.1 \pm 9.1^{\circ} \mathrm{C}$ (MacDonald et al., 2000), about $20^{\circ} \mathrm{C}$ warmer than normal bottom waters in the Gulf of Mexico at comparable depths. Rapid temperature changes at the brine-seawater interface (from $6^{\circ} \mathrm{C}$ to $48^{\circ} \mathrm{C}$ ) were documented over short time periods ( $\sim$ days), underscoring the ephemeral nature of fluid flow at this site (MacDonald et al., 2000). For long periods of time (from mid-January to April 1998), the temperature at the brine-seawater interface was $>20^{\circ} \mathrm{C}$ warmer than normal bottom water temperatures. Such lengthy and vigorous venting of warm fluids would be expected to result in considerable instability in the brine (MacDonald et al., 2000).

In 1998 , the near surface $(\sim 0.5 \mathrm{~m}$ below the interface) temperature of the GB425 brine was about $15^{\circ} \mathrm{C}$ warmer than temperatures observed in the GC233 brine. Such elevated temperatures near the brine-seawater interface can only be explained by the venting of deeply derived, hot brine fluids. These data, together with our visual observations of vigorous venting, suggest that the GB425 site supported higher rates of fluid flow than GC233, which would result in increased gas and oil release from the GB425 brine to the surrounding environment. While we cannot presently constrain fluid flow rates at either of these sites, the available data show clearly that the physical regime of these two sites is different. Quantifying rates of fluid flow from each of these sites, and from other brines in the Gulf of Mexico, is a worthy goal for future studies.

\subsection{Geochemical signatures of deep-sea brines}

Fluid flow at the mud volcano and the brine pool clearly influenced the geochemical signature of both brines as well as the distribution and activity of microorganisms in the brine fluids (Joye et al., 2005 ${ }^{1}$ ). Both brines were gas-charged,

\footnotetext{
${ }^{1}$ Joye, S. B., Samarkin, V. S., MacDonald, I. R., Elvert, E., Hinrichs, K.-U., Orcutt, B. N., and Montoya, J. P.: Dynamic Patterns of Microbial Activity in Gulf of Mexico Seafloor Brines, in preparation, 2005.
} 
containing a mixture of C1-C5 hydrocarbons that was dominated by methane. Most of the methane fluxing from the seafloor in the Gulf of Mexico is derived from thermogenic processes (Brooks et al., 1984). The predominance of methane in the gas mixture seeping from the brines $(>98 \%$ $\mathrm{CH}_{4}$ ) and the $\delta^{13} \mathrm{C}$ of that methane ( -66 to $-60 \%$ VPBD) suggested a mixed thermogenic and biogenic source at both sites (Table 1). At the GC233 brine pool, trace quantities of ethane and propane were observed and butane, iso-butane and pentane were not detectable. In contrast, at the GB425 mud volcano, ethane and propane concentrations were two to three orders of magnitude higher than those observed at GC233 and butane, iso-butane and pentane concentrations were substantial, suggesting a larger input of thermogenic gas at this site (data not shown).

Vigorous gas discharge from the mud volcano created walls of bubbles that emanated along fault tracks for 10's of meters (Joye et al., personal observation and video documentation). The gas plume rising from the mud volcano as visualized using CHIRP sonar (data not shown) reached $>200 \mathrm{~m}$ above the seafloor (Joye et al., unpublished data) whereas the sparse bubble stream at GC233 was not visible in CHIRP traces (De Beukelaer et al., 2003). Methane-rich plumes originating from cold seeps, such as those documented in the Gulf of Mexico (Aharon et al., 1992a; MacDonald et al., 2000; MacDonald et al., 2002) are common features along continental margins across the globe (Charlou et al., 2003 and references therein). Seafloor mud volcanoes, in particular, are likely important, but poorly constrained, sources of methane to the overlying water column and potentially to the atmosphere (Milkov, 2000; Dimitrov, 2002). Future studies in the Gulf of Mexico and elsewhere should aim to quantify the role of seafloor mud volcanoes in regional and global methane budgets. Such inputs of a labile reduced carbon source to bottom waters could fuel production by methanotrophic bacteria, which could be an important food source to benthic animals and water column secondary producers.

The depth distribution of major ions in the two brines differed. The seawater-brine mixing zone in the GC233 brine pool extended over more than one meter. In contrast, the seawater-brine transition occurred abruptly in the GB425 mud volcano, with a small change in salinity observed between 30 and $60 \mathrm{~cm}$ and a 3 -fold increase in salinity observed between 60 and $90 \mathrm{~cm}$. We were not able to position the trapper in areas of vigorous gas venting at the mud volcano because we could not identify the brine-seawater interface in turbulently mixed areas. Therefore, the gradients apparent in the mud volcano profile provide only a conservative estimate of mixing and are not representative of intensely mixed regions.

Sulfate was rapidly depleted to zero within the mud volcano brine but low $(<1 \mathrm{mM})$ concentrations persisted at depth within the brine pool. We propose that these low sulfate concentrations were maintained by anaerobic $\mathrm{H}_{2} \mathrm{~S}$ oxidation coupled to reactive metal $(\mathrm{Fe}, \mathrm{Mn})$ oxide reduction.
Sulfate reduction occurs at high rates in the GC233 brine (exceeding $1 \mu \mathrm{M} \mathrm{d}^{-1}$; Joye et al., $2005^{1}$ ) and $\mathrm{Fe}^{2+}$ concentrations are substantial $\left(\sim 90 \mu \mathrm{M}\right.$, Fig. 10) while $\mathrm{H}_{2} \mathrm{~S}$ concentrations are barely detectable ( $2 \mu \mathrm{M}$; data not shown), suggesting a potential coupling of iron oxide reduction to $\mathrm{H}_{2} \mathrm{~S}$ oxidation, which has been observed in the nearby Orca Basin brine (Van Cappellen et al., 1998). The abundance of suspended particulates documented in the brine provide an iron oxide source to fuel sulfide oxidation. The low $\mathrm{SO}_{4}^{2-}$ concentrations observed at the mud volcano likely result from a combination of microbial uptake as well as dilution by the upwardly advecting $\mathrm{SO}_{4}^{2-}$-free brine. Sulfate reduction rates at GB425 were an order of magnitude lower than those observed at GC233 (Joye et al., 2005 ${ }^{1}$ ) so microbial uptake alone cannot explain the sulfate profile. Advection of $\mathrm{SO}_{4}^{2-}$ free brine from depth would generate a steep $\mathrm{SO}_{4}^{2-}$ concentration gradient, even if microbial $\mathrm{SO}_{4}^{2-}$ reduction rates were low.

The concentration, depth distribution, and ratio of $\mathrm{Mg}^{2+}$, $\mathrm{Ca}^{2+}$ and $\mathrm{K}^{+}$to $\mathrm{Cl}^{-}$were surprisingly variable between the two brines. The concentration of $\mathrm{Mg}^{2+}$ was slightly higher in the brine pool ( 9.8 vs. $8.8 \mathrm{mM}$, Figs. 7 and 8 , Table 2 ). However, the $\mathrm{Mg} / \mathrm{Cl}$ ratio was identical at both sites (0.02) and did not vary with depth, suggesting no net difference in $\mathrm{Mg}^{2+}$ sources/sinks between the sites. The slight decrease in $\mathrm{Mg}^{2+}$ concentration over depth observed at both sites may result from dolomite or low-magnesium calcite precipitation (Charlou et al., 2003). The DIC concentrations observed in both brines were much lower than those $(>10 \mathrm{mM})$ observed in nearby sediments (Joye et al., 2004; Orcutt et al., 2005) and may have resulted from DIC removal via carbonate precipitation, particularly at the GC233 site. However, calcium concentrations in both brines increased with depth, and the observed increase was higher in the mud volcano (5.5X increase) than in the brine pool (3.5X increase) (Fig. 7, Table 2). Likewise, the $\mathrm{Ca} / \mathrm{Cl}$ ratio increased from about 0.02 (overlying seawater) to 0.6 in the brine pool and 0.10 in the mud volcano, illustrating a net increase in $\mathrm{Ca}^{2+}$ at depth. The increase in $\mathrm{Ca}^{2+}$ could reflect replacement of $\mathrm{Ca}^{2+}$ in carbonates by $\mathrm{Mg}^{2+}$ (dolomitization) or differences in $\mathrm{Ca}^{2+}$ concentrations in the source fluid (see below).

Potassium $\left(\mathrm{K}^{+}\right)$concentrations decreased by a factor of 2 with depth at the brine pool $(20 \mathrm{mM}$ in the brine) but increased by a factor of 2 with depth in the mud volcano (90 $\mathrm{mM}$ in the brine) (Table 2). Clay mineral reactions at depth below the seafloor likely contributed to the variations in $\mathrm{K}^{+}$concentrations we observed. Lower $\mathrm{K}^{+}$concentration in the GC233 brine could reflect kaolinization of illite, which removes $\mathrm{K}^{+}$from solution at depth (Land and McPherson, 1992). Similarly, $\mathrm{K}^{+}$can be enriched in brines by the dissolution or albitization of $\mathrm{K}^{+}$-rich feldspars (Land and McPherson, 1992) or by the dissolution of sylvite (Aharon et al., 1992b). High temperature $\left(\sim 40^{\circ} \mathrm{C}\right)$ reactions between the brine fluid and sediments may also promote $\mathrm{K}^{+}$ 
enrichment in brines (Charlou et al., 2003). The temperatures documented at the mud volcano (brine $\mathrm{T}>40^{\circ} \mathrm{C}$; MacDonald et al., 2000) are sufficient to support high temperature reactions capable of enriching $\mathrm{K}^{+}$in the brine. The on-going discharge of mud from the GB425 mud volcano requires that brine be constantly recharged from a deeper source. In contrast, the relative stability of the GB233 brine pool could make processes such as kaolinization, which deplete $\mathrm{K}^{+}$ from the pool fluids, more important over protracted time periods.

The differences in salt composition suggests that the two brines either originated from different sources or have reacted differently with sediments during transit from deep reservoirs. Two major salt depositional events occurred in the Gulf of Mexico, one during the Mesozoic and one during the Cenozoic. Most Mesozoic evaporites in the Gulf of Mexico are Ca-type evaporates while most Cenozoic evaporates are Na-Cl type evaporites (Land and McPherson, 1992). The sodium to chloride ratio $(\mathrm{Na} / \mathrm{Cl})$ in both the brines we examined exceeded the $\mathrm{Na} / \mathrm{Cl}$ ratio (0.82) of seawater (Fig. 8). The $\mathrm{Na} / \mathrm{Cl}$ ratio in the deeper samples collected from the brine pool was as high as 0.94 , suggesting the brine was derived largely from halite dissolution (most likely Cenozoic $\mathrm{Na}$-rich evaporites). In contrast, the most elevated $\mathrm{Na} / \mathrm{Cl}$ ratio observed in the deeper samples collected from the mud volcano was at most 0.86 , suggesting the brine has been diluted substantially with seawater and/or that it was derived from dissolution of a mixed salt (e.g., halite/sylvite) deposit. Sylvite dissolution and subsequent $\mathrm{K}^{+}$and $\mathrm{Cl}^{-}$contribution to the GB425 brine could help explain the observed $\mathrm{K}^{+}$enrichment in this brine but would also result in geochemical differences that were not observed. Contributions of gypsum and/or anhydrite dissolution to either brine are unlikely because this would increase $\mathrm{Ca} / \mathrm{Cl}$ and $\mathrm{SO}_{4} / \mathrm{Cl}$ ratios, which is the opposite from what we observed. The temporal evolution of brine geochemistry is discussed further in Sect. 4.3.

Few data on nutrient concentrations in deep-sea brines are available. While some data on ammonium or phosphate concentration are available, few measurements of silicate and nitrate concentrations have been reported. Nutrient distributions in these two brines followed similar trends, although absolute concentrations of nutrients varied between the brines. Phosphate concentrations were low at both sties $(<5 \mu \mathrm{M})$ and there was little variation in concentration over depth. The average phosphate concentration in bottom waters and brines was similar (Table 2). Nitrate concentrations were high (ca. $30 \mu \mathrm{M}$ ) in overlying bottom water. Nitrate concentration in both brines was low ( $\leq 1 \mu \mathrm{M}$, Fig. 9) but measurable and $\mathrm{NO}_{3} / \mathrm{Cl}$ mixing curves suggested conservative mixing between the overlying seawater and the brines (data not shown). Though denitrification could occur in the anoxic brines, available data suggest that if the process occurs, it occurs at low rates (at GB425) if at all (at GC233), and that is not a particularly important metabolic pathway.

Silicate and ammonium concentrations were elevated in both brines relative to the overlying seawater (Table 2). The highest silicate concentrations were observed at the base of the seawater-brine mixing zone but concentrations in the deepest chambers of the brine trapper were also substantially elevated above seawater concentrations (Fig. 9, Table 2). Both brines were enriched in silicate by about a factor of 8 relative to bottom water (Table 2 ). Given the elevated silicate concentration, the brines may be an important source of silicate to bottom waters. Ammonium concentrations in both brines were extremely high (up to $11 \mathrm{mM}$ ), resulting in extreme enrichment of ammonium in the brines (by over 100x) relative to bottom water. Similarly high concentrations of $\mathrm{NH}_{4}^{+}$have been reported from other brines in the Mediterranean (3 mM, Sass et al., 2001; $20 \mathrm{mM}$, Aloisi et al., 2004; Table 3) but an explanation for these high $\mathrm{NH}_{4}^{+}$concentrations is lacking.

Two potential mechanisms could lead to elevated silicate and ammonium concentrations in these brines. Seafloor brine pools may serve as traps for particles and for organisms (e.g., fish or mussels) that die and sink into the pool (MacDonald, 1992). Silicate and ammonium may be subsequently leached from the trapped inorganic particles and ammonium may be subsequently mineralized from organic debris. Increased cation concentration in solution enhances $\mathrm{Si}-\mathrm{O}$ bond hydrolysis (Dove, 1999), so, increased salinity may effectively leach silicate from $\mathrm{Si}$-rich particles that are trapped in seafloor brines. Particle-bound $\mathrm{NH}_{4}^{+}$represents an important $\mathrm{NH}_{4}^{+}$pool in sediments and particles and the method for quantifying this $\mathrm{N}$ pool involves extraction in a high ionic strength salt solution (typically either $2 \mathrm{M} \mathrm{KCl}$ or $\mathrm{NaCl}$ ) which desorbs $\mathrm{NH}_{4}^{+}$from the solid phase (Rosenfeld, 1979; Mackin and Aller, 1984). $\mathrm{NH}_{4}^{+}$could thus be desorbed from particles trapped in hypersaline seafloor brines. Ammonium could also be generated by the mineralization of organic material that is trapped within brine. An additional mechanism of $\mathrm{NH}_{4}^{+}$and silicate enrichment could arise via desorption of $\mathrm{NH}_{4}^{+}$from clay minerals or dissolution of silicate in clay minerals as the brine migrates upward through the sediment column. It is possible that the transit of brine through deep sediments could efficiently concentrate $\mathrm{NH}_{4}^{+}$and silicate in the advecting brine. Since the deepest brine samples were substantially elevated in $\mathrm{NH}_{4}^{+}$and silicate, it is likely that processes occurring during brine transport through deep sediments contribute substantially to the observed concentration enrichments.

Because of the high $\mathrm{NH}_{4}^{+}$concentration, the DIN/DIP ratio $\left(=\left(\left(\mathrm{NO}_{3}^{-}+\mathrm{NH}_{4}^{+}\right) / \mathrm{HPO}_{4}^{2-}\right)\right)$ of the brine $(>1000$ and up to $6000)$ greatly exceeded that in the bottom water $(\sim 40)$. However, the majority of the brine-derived $\mathrm{NH}_{4}^{+}$is consumed, possibly via nitrification, during mixing of the brine with seawater. This impact of this $\mathrm{N}$ input in terms of driving DIP limitation of biological processes in the overlying water column or in surficial sediments is not known at present. 


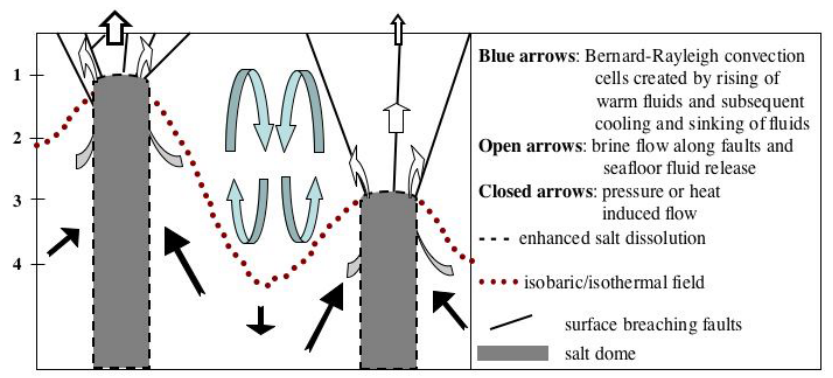

Fig. 11. Cartoon showing hypothetical driving mechanisms of fluid flow around salt bodies. The salt body distorts (pulls upward) geopressure and geothermal gradients and enhanced dissolution at the edge of the salt generates brines that flow along pressure and heat gradients. During transit, concentrated brines may be diluted with bottom seawater in Bernard-Rayleigh convection cells and ultimately, variably diluted brines are released at the seafloor along faults (see text for further discussion).

\subsection{Brine sources and flow dynamics}

The presence of salt deposits throughout the Gulf of Mexico basin is well documented (e.g., Bryant et al., 1991); however, the mechanisms governing the production, movement and ultimate release of brine fluids from the seafloor is not well understood. The presence of salt bodies influences fluid flow in the sediment column because of 1) salt movement and 2) salt-induced thermal focusing (Bennett and Hanor, 1987; Lerche and Petersen, 1995). Salt movement is driven by density differences between the salt and the surrounding sediment. While salt is more dense $\left(\sim 2.2 \mathrm{~g} \mathrm{~cm}^{-3}\right)$ than freshly deposited sediments $\left(1.6-1.9 \mathrm{~g} \mathrm{~cm}^{-3}\right.$ on average, though carbonates are more dense, $2.2-2.3 \mathrm{~g} \mathrm{~cm}^{-3}$ ), salt is less dense than compacted, dewatered sediment (2.6$2.8 \mathrm{~g} \mathrm{~cm}^{-3}$; Lerche and Petersen, 1995). Salt is incompressible, so at some point during burial, the salt body is less dense than the surrounding sediments and becomes buoyant. Since salt has little mechanical strength, the less dense salt is mobilized and flows fluid-like from areas of over-pressure. Mobile salt bodies lengthen and stretch in an attempt to reach neutral buoyancy with the surrounding materials (Lerche and Petersen, 1995).

Over time, as sediments are buried and compacted, pore fluids are expelled. Brines may form if these expelled fluids come into contact with salt bodies. Seawater is substantially undersaturated with salt, containing only $3.5 \%$ salt compared to saturation values of $25-30 \%$ salt. Thus, if saltundersaturated connate fluids come into contact with salt bodies, the salt dissolves and this increases the density of the fluid. These salty, dense fluids sink until they are heated, which decreases the density and increases buoyancy.

Salt bodies generate geopressure gradients because of salt movement and thermal gradients caused the enhanced thermal conductivity of salt, which generates thermal gradients in the salt body and adjacent sediments. The thermal conductivity of salt (e.g., halite) is about three times that of sediment. Thus, salt bodies focus heat and the sediments surrounding salt are substantially warmer (by $10-15^{\circ} \mathrm{C}$ ) than sediments 6 or more km away from salt body (Bennett and Hanor, 1987). Interestingly, temperature isotherms around salt bodies are displaced upward while isotherms $2-4 \mathrm{~km}$ from the salt body can be displaced downward (Bennett and Hanor, 1987; Fig. 11), suggesting that large-scale patterns of fluid flow are driven by the presence of salt bodies. Such geopressure and thermal gradients represent km-scale flow cells around salt bodies, known as Bernard-Rayleigh convection cells (Bennett and Hanor, 1987; Fig. 11). Evidence for the existence of such large-scale flow features include thermal, pressure and salt gradients documented around salt domes (Bennett and Hanor, 1987; Lerche and Petersen, 1995) but examples of this process are limited and details of the physical dynamics of such fluid flows are not available.

We hypothesize that the depth of the salt body below the seafloor may impact the flow regime of the system as well as the thermal signature of the advecting brine. For areas underlain by shallow salt bodies, such as the GB425 site (left salt body on Fig. 11), more vigorous discharge of hot brine could be driven by rapid advection along the flanks of the deeply-rooted salt body. A complex network of surficial faults, driven both by salt movement and the shallow nature of the salt body, could further facilitate brine expulsion. In contrast, at areas underlain by deeper salt bodies, such as the GC233 site (right salt body on Fig. 11), the brine has more opportunity to cool during ascent through a potentially less complex fault network, resulting in expulsion of cooler fluids and less vigorous discharge regimes. Variations in fluid flow such as those we propose would impact microbial dynamics in deep sediments as well as in seafloor brines. Additional data are needed to elucidate the impact of such large-scale circulation on the sediment microbiology and biogeochemistry in the vicinity of salt domes.

Active Bernard-Rayleigh circulation cells help explain the geochemical signatures of the GB425 and GC233 brines. While the salinity of the GC233 and GB425 brines ( 130\%) is significantly lower than that expected for concentrated brine resulting from halite dissolution $(\sim 300 \%$; Lerche and Petersen, 1995), the brine $\mathrm{Na}: \mathrm{Cl}$ ratios are elevated ( 0.85 to $0.94)$ above the bottom water value $(0.82)$. The brines are thus not merely connate waters to which salt has been added. Rather, it appears that the concentrated brines have been diluted significantly with seawater. Since the concentrations of $\mathrm{Cl}^{-}$and $\mathrm{Na}^{+}$in the two brines were not significantly different, it appears they were similarly diluted with seawater during transit from deep reservoirs. The salinity and $\mathrm{Na} / \mathrm{Cl}$ ratio of the brines we studied could be explained by dilution of a halite brine having a salinity of $300 \%$ with seawater in a ratio of 45 parts concentrated brine to 55 parts seawater. Though the brine could be derived from residual evaporated seawater that had not reached the halite precipitation stage 
(Vengosh et al., 1998), dilution and mixing with seawater is also a plausible explanation.

While sylvite dissolution could result in the elevated $\mathrm{K}^{+}$ documented at GB425, this would not explain the $\mathrm{Na} / \mathrm{Cl}$ ratios (0.85 at GB425 and 0.87 at GC233) observed in the two brines. Inputs of $\mathrm{Cl}^{-}$from sylvite dissolution at GB425 would generate a lower $\mathrm{Na} / \mathrm{Cl}$ ratio $(\sim 0.83)$, assuming input of an equimolar amount of $\mathrm{Cl}^{-}$relative to $\mathrm{K}^{+}$. Thus we suspect that both brines originated from dissolution of a similar salt body, likely halite rather than a mixed halite-sylvite salt body and that significant reaction of the hot $\left(>40^{\circ} \mathrm{C}\right)$ brine with sediments during transit to the surface generated the observed $\mathrm{K}^{+}$enrichment at GB425 (Charlou et al., 2003).

\section{Summary}

The geochemical signatures of the two brine systems described here result from variations in the source fluid as well as high temperature reactions between brines and sediment as brines ascend from deep reservoirs to the seafloor. Unlike many of the brines in the Mediterranean (Table 3; Sass et al., 2001; Charlou et al., 2003), the Gulf of Mexico brines contain low concentrations sulfide and little to no sulfate. Sulfate-enriched brines have been documented at deeper sites in the Gulf of Mexico (Aharon et al., 1991) and these brines may derive from dissolution of gypsum and anhydrite. The low concentration of sulfate present in the brines we studied means that methanogenesis could be an important microbial metabolic process in these environments (Joye et al., 2005 ${ }^{1}$ ). The mechanism of silicate and $\mathrm{NH}_{4}^{+}$enrichment in the brines warrants further study. It is likely that both deep and surficial processes contribute to the enrichment of these constituents in the brines. High concentrations of $\mathrm{CH}_{4}$ and $\mathrm{NH}_{4}^{+}$, in particular, in the brines makes fluid flow from mud volcanoes an important source of energy rich compounds to the surrounding environment. In all likelihood, methanotrophic and nitrifying bacteria in the overlying water column consume these materials shortly after their release, making mud volcanoes and brine pools important sources of reduced materials that fuel chemoautotrophic processes that are commonly associated with ocean floor cold seeps. Documenting and understanding salt-induced fluid flow regimes in deep sediments and relating those flow regimes to seafloor brine biogeochemistry is a fertile area for future research.

Acknowledgements. We thank members of science parties of the CHEMO 1997, CHEMO 1998 and LExEn 2002 research cruises, the crew of the R/V Seward Johnson II, and the pilots and crew of the deep submergence vehicle Johnson Sea Link for assistance with sample collection. B. Orcutt, M. Erickson, H. Mills, and P. Sobecky assisted with preparation of the brine trapper and/or processing/analysis of brine samples. A. Pachachy assisted with the design of the brine trapper and processing the geochemical data in 1998. This research was supported by the National Science Foundation "Life in Extreme Environments" Program (OCE-0085549), the American Chemical Society (PRF-36834-AC2), and the U.S. Department of the Interior's Minerals Management Service (contract nos. 14-35-0001-30555 and 14-35-0001-31813). The U.S. Department of Energy, the Minerals Management Service, the National Undersea Research Program, and the Georgia Institute of Technology provided financial support for submersible operations. We are deeply indebted to R. Carney and an anonymous reviewer for providing insightful comments that significantly improved this paper.

Edited by: A. Boetius

\section{References}

Aharon, P., Graber, E. R., and Roberts, H. H.: Dissolved carbon and $\mathrm{d}^{13} \mathrm{C}$ anomalies in the water column caused by hydrocarbon seeps on the northwestern Gulf of Mexico slope, Geo-Mar. Lett., 12, 33-40, 1992a.

Aharon, P., Roberts, H. H., and Snelling, R.: Submarine venting of brines in the deep Gulf of Mexico; observations and geochemistry, Geol., 20, 483-486, 1992b.

Aloisi, G., Drews, M., Wallmann, K., et al.: Fluid expulsion from the Dvurechenskii mud volcano (Black Sea): Part I. Fluid sources and relevance to $\mathrm{Li}, \mathrm{B}, \mathrm{Sr}, \mathrm{I}$ and dissolved inorganic nitrogen cycles, Earth Plan. Sci. Let., 225, 347-363, 2004.

Anschutz, P., Turner, J. S., and Blanc, G.: The development of layering, fluxes through double-diffusive interfaces, and location of hydrothermal sources of brines in the Atlantis II Deep: Red Sea, J. Geophys. Res., 103, 27 809-27 819, 1998.

Bennet, S. S. and Hanor, J. S.: Dynamics of subsurface salt dissolution at the Welsh Dome, Louisiana Gulf Coast, 653-677. in: Dynamical Geology of Salt and Related Structures, edited by: Lerche, I. and O'Brien, J. J., Academic Press, Orlando, 1987.

Bouma, A. H. and Bryant, W. R.: Physiographic features of the northern Gulf of Mexico continental slope, Geo-Mar. Let., 14, 252-263, 1994.

Brooks, J. M., Kennicutt, M. C., Fay, R. R., et al.: Thermogenic gas hydrates in the Gulf of Mexico, Science, 223, 696-698, 1984.

Brooks, J. M., Wiesenburg, D. A., Roberts, H. H., et al.: Salt, seeps and symbiosis in the Gulf of Mexico, EOS, 71, 1772-1773, 1990.

Bryant, W. R., Simmons, G. R., and Grim, P. J.: The morphology and evolution of basins on the continental slope, northwest Gulf of Mexico, Transactions - Gulf Coast Assoc. Geol. Soc., 51, 7382, 1991

Bryant, W. R., Bryant, J. R., Feeley, M. H., et al.: Physiographic and bathymetric characteristics of the continental slope, northwest Gulf of Mexico, Geo-Mar. Let., 10, 182-199, 1990.

Carson, B. and Screaton, E. J.: Fluid flow in accretionary prisms: Evidence for focused, time-variable discharge, Rev. of Geophys., 36, 329-351, 1998.

Charlou, J. L., Donval, J. P., Zitter, T., et al.: Evidence of methane venting and geochemsitry of brines on mud volcanoes of the eastern Mediterranean Sea, Deep-Sea Res., 50, 951-958, 2003.

Cita, M. B.: Anoxic basins of the Mediterranean: An overview, Paleoceanogr., 6, 133-141, 1990.

Cita, M. B., Camerlenghi, A., Erba, E., et al.: Discovery of mud diaperism in the Mediterranean Ridge: a preliminary report, Bull. Soc. Geol. of Italy, 108, 537-543, 1989. 
Commeau, R., Paull, C. K., Commeau, J., et al.: Chemistry and mineralogy of pyrite-enriched sediments at a passive margin sulfide brine seep: abyssal Gulf of Mexico, Earth Plan. Sci. Let., 82, 62-74, 1987.

De Lange, G. J. and Brumsack, H.-J.: The occurrence of gas hydrates in Eastern Mediterranean mud dome structures as indicated by pore-water composition, 167-175, in: Gas Hydrates: Relevance to World Margin Stability and Climate Change, edited by: Henriet, J.-P. and Mienert, J., Geological Society, London, 1998.

Dimitrov, L. I.: Mud volcanoes-the most important pathway for degassing deeply buried sediments, Earth Sci. Rev., 59, 49-76, 2002.

Dove, P. M.: The dissolution kinetics of quartz in aqueous mixed cation solutions, Geochim. Cosmochim. Acta, 63, 3715-3727, 1999.

Eder, W., Schmidt, M., Koch, M., et al.: Prokaryotic phylogenetic diversity and corresponding geochemical data of the brineseawater interface of the Shaban Deep, Red Sea, Environ. Microbiol., 4, 758-763, 2002.

$\mathrm{Fu}, \mathrm{B}$., and Aharon, P.: Sources of hydrocarbon-rich fluids advecting on the seafloor in the Northern Gulf of Mexico, Transactions - Gulf Coast Assoc. Geol. Soc., XLVIII, 73-91, 1998.

Ginsburg, G. D., Milkov, A. V., Soloviev, V. A., et al.: Gas hydrate accumulation at the Haakon Mosby mud volcano, GeoMar. Lett., 19, 57-67, 1999.

Henry, P., Le Pichon, X., Lallemant, S., et al.: Fluid flow in and around a mud volcano field seaward of the Barbados accretionary wedge: Results from Manon cruise, J. Geophys. Res., 101, 20 297-20 324, 1996.

Humphris, C. C.: Salt movement in continental slope, northern Gulf of Mexico, AAPG Bull., 63, 782-798, 1979.

Joye, S. B., Boetius, A., Orcutt, B. N., et al.: The anaerobic oxidation of methane and sulfate reduction in sediments from Gulf of Mexico cold seeps, Chem. Geol., 205, 219-238, 2004.

Kalanetra, K., Joye, S. B., Sunseri, N. R., et al.: Novel, large, vacuolate, nitrate-accumulating sulfur bacteria discovered in the Gulf of Mexico reproduce by reductive division in three dimensions, Environ. Microbiol., 7, 1451-1460, 2005.

Kennicutt II, M. C., Brooks, J. M., and Denous, G. J.: Leakage of deep, reservoired petroleum to the near surface on the Gulf of Mexico continental slope, Mar. Chem., 24, 39-59, 1988a.

Kennicutt II, M. C., Brooks, J. M., Bidigare, R. R., et al.: Gulf of Mexico hydrocarbon seep communities-I: Regional distribution of hydrocarbon seepage and associated fauna., Deep-Sea Res., 35A, 1639-1651, 1988b.

Lance, S., Henry, P., Le Pichon, X., et al.: Submersible study of mud volcanoes seaward of the Barbados accretionary wedge: sedimentology, structure and rheology, Mar. Geol., 145, 255292, 1998

Land, L. S. and Macpherson, G. L.: Origin of Saline Formation Waters, Cenozoic Section, Gulf of Mexico Sedimentary Basin, AAPG Bull., 76, 1344-1362, 1992.

Langseth, M. G., Westbrook, G. H., and Hobart, A.: Geophysical survey of a mud volcano seaward of the Barbados Ridge complex, J. Geophys. Res., 93, 1049-1061, 1988.

Larkin, J., Aharon, P., and Henk, M. C.: Beggiatoa in microbial mats at hydrocarbon vents in the Gulf of Mexico and warm mineral springs, Florida, Geo-Mar. Let., 14, 97-103, 1994.
Lerche, I. and Petersen, K.: Salt and sediment dynamics, CRC Press, Boca Raton, 322 pages, 1995.

Limonov, A. F., Woodside, J., Cita, M. B., et al.: The Mediterranean Ridge and related mud diaperism: a background, Mar. Geol., 132, 7-19, 1996.

MacDonald, I. R.: Sea-Floor brine pools affect behavior, mortality, and preservation of fishes in the Gulf of Mexico: Lagerstätten in the Making?, Palaios, 7, 383-387, 1992.

MacDonald, I. R.: Natural Oil Spills, Sci. Amer., 279, 51-66, 1998.

MacDonald, I. R., Reilly, J. F., Guinasso, J. N. L., et al.: Chemosynthetic mussels at a brine-filled pockmark in the northern Gulf of Mexico, Science, 248, 1096-1099, 1990.

MacDonald, I. R., Buthman, D., Sager, W. W., et al.: Pulsed oil discharge from a mud volcano, Geol., 28, 907-910, 2000.

Macgregor, D. S.: Relationship between Seepage, tectonics and subsurface petroleum reserves, Mar. Petrol. Geol., 10, 606-619, 1983.

McGee, D. T., Bilinski, P. W., Gary, P. S., et al.: Geologic models and reservoir geometries of Auger Field, deepwater Gulf of Mexico, in: Submarine fans and turbidite systems - sequence stratigraphy, reservoir architecture, and production characteristics, edited by: Weimer, P., Bouma, A. H., and Perkins, B. F., SEPM, 233-244, 1993.

Mackin, J. E. and Aller, R. C.: Ammonium adsorption in marine sediments, Limnol. Oceanogr., 29, 250-257, 1984.

MEDINAUT/MEDINETH, S. S. P.: Linking Mediterranean Brine Pools and Mud Volcanism, EOS, 81, 625, 2000.

Milkov, A. V.: Worldwide distribution of submarine mud volcanoes and associated gas hydrates, Mar. Geol., 167, 29-42, 2000.

Nikolaus, R., Ammerman, J. W., and MacDonald, I. R.: Distinct pigmentation and trophic modes in Beggiatoa from hydrocarbon seeps in the Gulf of Mexico, Aquat. Microb. Ecol., 32, 85-93, 2003.

Nix, E. R., Fisher, C. R., Vodenichar, J., et al.: Physiological ecology of a mussel with methanotrophic endosymbionts at three hydrocarbon seep sites in the Gulf of Mexico, Mar. Biol., 122, 605617, 1995.

Neurauter, T. W. and Roberts, H. H.: Three generations of mud volcanoes on the Louisiana continental slope, Geo-Mar. Lett., 14, 120-125, 1994.

Neurauter, T. W. and Bryant, W. R.: Seismic expression of sedimentary volcanism on the continental slope, Northern Gulf of Mexico, Geo-Marine Letters, 10, 225-231, 1990.

Orcutt, B., Boetius, A., Elvert, M., Samarkin, V., and Joye, S.: Molecular biogeochemistry of sulfate reduction, methanogenesis and the anaerobic oxidation of methane at Gulf of Mexico cold seeps, Geochim. Cosmochim. Acta, 69, 4267-4281, 2005.

Pindell, J.: Alleghenian reconstruction and subsequent evolution of the Gulf of Mexico, Bahamas and proto-Caribbean Sea, Tectonics, 4, 1-39, 1985.

Popp, B. N., Sansone, F. J., Rust, T. M., et al.: Determination of concentration and carbon isotopic composition of dissolved methane in sediments and near shore waters, Analy. Chem., 67, 405-411, 1995.

Reilly, J. F., MacDonald, I. R., Biegert, E. K., et al.: Geologic controls on the distribution of chemosynthetic communities in the Gulf of Mexico, in: Hydrocarbon migration and its nearsurface expression, edited by: Schumacher, D. and Abrams, M. A., Amer. Assoc. Petrol. Geol., Tulsa OK, 38-61, 1996. 
Roberts, H. H. and Carney, R. S.: Evidence of episodic fluid, gas, and sediment venting on the northern Gulf of Mexico continental slope, Econ. Geol., 92, 863-879, 1997.

Rosenfeld, J. K.: Ammonium absorption in nearshore anoxic sediments, Limnol. Oceanogr., 24, 356-364, 1979.

Sager, W. W., MacDonald, I. R., and Hou, R. S.: Geophysical signatures of mud mounds at hydrocarbon seeps on the Louisiana continental slope, northern Gulf of Mexico, Mar. Geol., 198, 97132, 2003.

Sass, A. M., Aass, H., Coolen, M. J. L., et al.: Microbial Communities in the Chemocline of a Hypersaline Deep-Sea Basin (Urania Basin, Mediterranean Sea), Appl. Environ. Microbiol., 67, 53925402, 2001.

Schmidt, M., Botz, R., Faber, E., et al.: High-resolution methane profiles across anoxic brine-seawater boundaries in the AtlantisII, Discovery, and Kebrit deeps (Red Sea), Chem. Geol., 200, 359-376, 2003.

Sheu, D. D.: The Anoxic Orca Basin (Gulf of Mexico): Geochemistry of Brines and Sediments, Rev. Aquat. Sci., 2, 491-507, 1990.

Shew, R. D., Rollins, D. R., Tiller, G. M., et al.: Characterization and modeling of thin bedded turbidite deposits from the Gulf of Mexico using detailed subsurface and analog data, in: Submarine fans and turbidite systems - sequence stratigraphy, reservoir architecture, and production characteristics, edited by: Weimer, P., Bouma, A. H., and Perkins, B. F., SEPM, 327-334, 1993.
Shokes, R. F., Trabant, P. K., Presley, B. J., et al.: Anoxic, Hypersaline Basin in the Northern Gulf of Mexico, Science, 196, 1443-1446, 1977.

Solaranzo, L.: Determination of ammonia in natural waters by the phenol hypochlorite method, Limnol. Oceanogr., 14, 799-801, 1969.

Stookey, L. L.: Ferrozine - A new spectrophotometric reagent for iron, Analy. Chem., 42, 779-781, 1970.

Van Cappellen, P., Viollier, E., Roychoudhury, A., et al.: Biogeochemical Cycles of Manganese and Iron at the Oxic-Anoxic Transition of a Stratified Marine Basin (Orca Basin, Gulf of Mexico), Environ. Sci. Technol., 32, 2931-2939, 1998.

Vengosh, A., de Lange, G. J., Gert, J., et al.: Boron isotope and geochemical evidence for the origin of Urania and Bannock brines at the eastern Mediterranean: effect of water-rock interactions, Geochim. Cosmochim. Acta, 62, 3221-3228, 1998.

Worrall, D. M. and Snelson, S.: Evolution of the northern Gulf of Mexico, with emphasis on Cenozoic growth faulting and the role of salt, in: Decade of North American Geology, edited by: Bally, A. and Palmer, A., Geological Society of America, Boulder, CO, 97-138, 1989. 